\title{
CHUPETA: COMO ORIENTAR OS PAIS
}

\section{Christiane Luiza SANTOS, José Vítor Nogara Borges MENEZES}

A remoção da chupeta é geralmente um grande desafio para pais e profissionais da área de saúde. Este hábito tem um aspecto etiológico multifatorial, normalmente iniciado por um determinado motivo, sustentado por outro e nas idades subseqüentes, mantido por reforços de caráter emocional (QUELUZ et all, 1999). O principal objetivo deste trabalho é, através de uma revisão da literatura, mostrar abordagens profissionais que busquem minimizar as conseqüências nocivas do hábito de sucção de chupetas. As formas de orientar os pais para evitar a instalação do hábito, desde os primeiros meses de vida do bebê, através do estímulo ao aleitamento materno e exercícios específicos para a satisfação da necessidade de sucção natural do bebê serão mostrados. Outro aspecto a ser realçado é a opção preferencial pelas chupetas ortodônticas, pois estas se adaptam melhor às estruturas mio-faciais das crianças, apesar de causarem danos em proporções semelhantes à convencional (ZARDETTO et al., 2002). A revisão de literatura mostrou que existem três momentos ideais para fazer a remoção do hábito: ao irromper dos primeiros dentes decíduos; aos três anos; e quando a criança atinge certa maturidade emocional, por volta de quatro a cinco anos. A remoção do hábito deve ser embasada no complexo individual, envolvendo aspectos pessoais, emocionais, psicológicos, familiares e sociológicos da criança (GUEDES-PINTO, 2005). 